\title{
Aggregation And Spatial Coexistence of Earthworm Community in Grassy Savanna of Lamto (Côte d'Ivoire)
}

\author{
Seydou Tiho \\ UFR des sciences de la nature (UFR-SN), Université Nangui Abrogoua \& station d'écologie \\ de Lamto, 02 BP 801 Abidjan 02, Côte d'Ivoire \\ E-mail: setiho@hotmail.com
}

N'guetta Moise Ehouman(Corresponding author)

UFR des sciences de la nature (UFR-SN) Université Université Nangui Abrogoua \& station d'écologie de Lamto, 02 BP 801 Abidjan 02, Côte d'Ivoire

Tel: 225-0803-6010Ｅ-mail: ehoumanmoise981@ gmail.com

Mamadou Dagnogo

UFR des sciences de la nature (UFR-SN)

Université Nangui Abrogoua, 02 BP 801 Abidjan 02, Côte d'Ivoire.

E-mail: mdagnogo2002@yahoo.fr

Received: January 20, 2015 Accepted: February 4, 2015

doi:10.5296/jbls.v6i2.6975 URL: http://dx.doi.org/10.5296/jbls.v6i2.6975

\begin{abstract}
Understanding of mechanisms by which species spatially coexist, come from the theoretical framework and has focussed on spatial competition. Earthworms were sampled in rainy season on a grid obtained from grassy savanna to explore spatial competition. We used geostatistical analysis to assess spatial dependence within community between different population patterns. Empirical results revealed among earthworm community two groups of species appeared of interest in term of association. The Eudrilidae species (Stuhlmannia porifera, Chuniodrilus zielae, and Chuniodrilus spl) on the one part were negatively associated with Millsonia omodeoi (Megascolecidae) on the other part, whereas we observed significant positive association between C.zielae and S.porifera. This study indicates that the competitive
\end{abstract}


interaction structures the community and this competition is detected through reduced density of one competitor when they spatially collocated.

Keywords: Earthworm community, Geostatistical analysis, Spatial dependence, Competition, Lamto

\section{Introduction}

Soils are one of the last great frontiers for biodiversity research and are home to an extraordinary range of microbial and animal groups. Biological activities in soils drive many of the key ecosystem processes that govern the global system, especially in the cycling of elements such as carbon, nitrogen and phosphorus.

The direct contribution of decomposer invertebrates to energy flow and carbon mineralization is low (about 10\%) (Schaefer 1991), whereas the direct effect on nutrient mineralization is somewhat higher ( 30\%) (Verhoef and Brussard, 1990; De Ruiter et al., 1993). However, the indirect effect of soil invertebrates on litter decomposition through litter fragmentation and modifications of the structure and activity of the microbial community considerably exceeds the direct effect via their own metabolism (Hättenschwiler et al., 2005; Bohlen and Edwards, 1995).

Soil macroinvertebrates such as earthworms are key players in the soil processes. In African tropical wet savannas, earthworms dominate soil macroinvertabrate biomass (Lavelle, 1978) and are major ecosystem engineers. Through their activities they significantly influence soil properties (e.g. macroporosity) and processes (e.g. water infiltration, nutrient and carbon cycling, carbon sequestration in their cast). Evidence suggests that the diversity of earthworm species is important for microbial community composition and activity via the so-called prime effect. Ample evidence indicates that the different ecological groups of earthworms differentially affect the activity of soil microorganisms and decomposition processes (Shaw and Pawluk 1986; Brown et al., 2000). Experimental manipulations suggest that the loss of both functional groups and species diversity within functional groups of earthworms alters the ability of soil microorganisms to process organic substrates (Scheu et al., 2002).

Species loss or niche differentiation among species within communities suggests the existence of a form of organization through exerting control on species occurrence. In searching that structure, many studies (Jiménez et al., 2001; Rossi 2003a, 2003b, Rossi et al., 1997) have revealed the spatial distribution of earthworm.

Description of spatial patterns is rarely a goal per se. Rather; one generally wants to know the mechanism by which these spatial patterns are created. Earthworm populations exhibit an irregular and aggregated distribution that may be related to vegetation, soil characteristics and biotic interactions (Whalen, 2004; Nuutinen et al., 1998; Rossi et al., 1997). However, empirical studies available show no evidence that vegetation and soil characteristics structure the earthworm community. Our studies understanding of mechanisms by which species spatially coexist, come from the theoretical framework (Amarasekare, 2003) and has focused on spatial competition. 
This empirical study attempts to assess the spatial coexistence of earthworm in an African grassy savannah in (Lamto, Côte d'Ivoire) and explore the spatial competition within the community. To this end, geostatistical analysis was used to assess the spatial dependence among individuals of spatial distribution of the same earthworm species and between individuals of spatial different species. We finally discuss how our results highlight the relative importance of interspecific competition in the spatial structuring of these communities at the local scale.

\section{Material and Methods}

\subsection{Site Description}

The study site was located in the natural Reserve of Lamto $\left(6^{\circ} \mathrm{N}, 5^{\circ} 2 \mathrm{~W}\right)$ in Central Côte d'Ivoire. The reserve belongs to the transition zone between the semi-deciduous humid forest in the South and Soudanian savannas in the North. The 2700 ha of the reserve covered by a mosaic of forest and savanna is referred to Guinean savanna. The study plots are located in a grassy savanna maintained by annual burning. Lamto is characterized by a bimodal rainfall indicating two wet seasons from April to July and from September to October. Mean annual temperature over 10 years (2000 to 2010) was $28.4^{\circ} \mathrm{C}$ while rainfall is ranged between $8.4 \mathrm{~mm}$ in January and $189.7 \mathrm{~mm}$ in June with an annual sum of $1138.1 \mathrm{~mm}$. Most soils lie on granitic bedrock are slightly acidic and classified as ferralsols (FAO classification) and constituted of $75 \%$ of sand.

\subsection{Earthworms Sampling}

Earthworms sampling was carried out from July 2010 to September 2010 in rainy season on a 50 x $50 \mathrm{~m}$ plot obtained from grassy savanna, woody savanna and forest. The plot was gridded at $5 \mathrm{~m}$ intervals to yield a block system of 10 "columns" and 10 "rows"; giving a total of 100 subplots of $25 \mathrm{~m}^{2}$ each. A total of 100 monoliths of $50 \mathrm{~cm}$ side and $30 \mathrm{~cm}$ depth were systematically taken from the grid. Earthworms were extracted by direct hand sorting from the three successive strata of $10 \mathrm{~cm}$ depth (Lavelle, 1978). However for this study all the strata were combined and only data from grassy savanna were considered. Earthworms were all preserved in $4 \%$ formaldehyde. Individuals were identified in the laboratory to species level, counted and weighed. Species were determined using the taxonomic guides of Csuzdi and Tondoh (2007).

\subsection{Spatial Analysis}

\subsubsection{Correlation Matrix}

In exploratory spatial data analysis, relationships between the species were tested. In the very broadest sense, there are three patterns one can observe on a scatter plot: the variables are positively correlated, negatively correlated, or uncorrelated. Since the species coexistence is based on spatial competition in this work, only significantly negative association between species were selected.

Furthermore, we used XY-plot method from the lattice graphics package in R program to show the geographic distribution of the negative association between species. The XY-plot method 
allows the use of panel functions to superimpose different kinds of plots, in this case two points sets and the grid lines on top of the main XY (scatter) plot.

\subsubsection{Variogram}

In spatial statistics the theoretical variogram is a function describing the degree of spatial dependence of a spatial random field or stochastic process. It is defined as the variance of the difference between field values at two locations across realizations of the field (Rossi, 2003a). It is estimated as:

$$
2 \gamma(h)=\frac{1}{n(h)} \sum_{i=1}^{n(h)}\left[z(x i)-z(x i+h)^{2}\right]
$$

Where $n(h)$ is the number of sample pairs at each distance interval $h$ and $z(x i)$ and $z(x i+h)$ are the values of the variable at any two places separated by a distance $h$. The lag $h$ is a vector defined with both distance and direction.

The ' 2 ' in front of the $\gamma$ is there for mathematical convenience. The term $\gamma(h)$ is called the semi-variogram as the measure of the semi-variance. The semi-variance value when $\gamma(0)>0$ is known as nugguet variance $\left(C_{0}\right)$ and is caused both by sampling errors and by the spatial variability occuring within the minimum distance interval. The part of the variance attributed to spatial correlation is the spatial variance $(C)$. The sill $\left(C_{0}+C\right)$ is the asymptote of the model and the range (a) represents the distance up to which two samples are correlated. The percentage of spatial dependence $\left[C /\left(C_{0}+C\right)\right]$ measures the proportion of the variance of a sample, which is explained by the spatial variance $(C)$. If this proportion is close to 0 , then the spatial dependence is low (Cressie, 1993)

There are four common models used to fit semi-variograms but in this study only three models were explored: exponential, spherical, and gaussian. The exponential model is:

$$
\gamma(h)=C_{0}+C[1-\exp (-|h| / a)]
$$

Where $C_{0}+C$ is the sill, and $a$ is the range. The spherical model is: 


$$
\left\{\begin{array}{c}
\gamma(h)=C_{0}+C\left[(3 h / 2 a)-0.5(h / a)^{3}\right] \quad 0<h<a \\
C_{0}+C, h \leq a
\end{array}\right.
$$

The Gaussian model is:

$\gamma(h)=C_{0}+C\left[1-\exp \left(-h^{2} / a^{2}\right)\right]$ where terms are as defined above.

The relative variance is $C /\left(C+C_{0}\right)$ and the remaining variance is $C_{0} /\left(C+C_{0}\right)$

\subsubsection{Cross-Variogram}

Cross - variogram was used to assess the relationship between earthworm species (Millsonia omodeoi, Chuniodrilus zielae and Stuhlmannia porifera) in grassy savanna. The Megascolecid Millsonia omodeoi is a mesohumic endogeic (soil eater) earthworm that dominates the earthworm community in terms of biomass (Lavelle, 1978). This species is classified as a compacting earthworm because it increases soil bulk density (Lowe and butt, 1999) whereas Chuniodrilus zielae (Omodeo) and Stuhlmannia porifera (Omodeo and Vaillaud) are endogeic species and belong to the functional decompacting species because they tend to decrease soil bulk density (Lowe and Butt, 1999).

It was performed using Gstat from "R package". Cross-variogram is a spatial analysis technique in which two variables are used with the aim of examining the spatial co-structure between them. Two variables are defined as cross correlated if the values of one at a given location depend (in a statistical sense) on the values of the others at nearby locations. Such variables are also named co-regionalized reference to the theory of Matheron (1971). As two variables are handled simultaneously, the Cross Variogram operation can be seen as the multivariate form of the spatial correlation operation. Thus coregionalisation and cross-variogram are adequate tools to study interrelationships between different species density (Rossi et al., 1992). The spatial interdependence between V and W (two spatial variables) is expressed in the cross-variance estimated as:

$$
\gamma_{v w(h)=\frac{1}{2 n(h)}} \sum_{i=1}^{n(h)}[v(x i)-v(x i+h)][w(x i)-w(x i+h)]
$$

Where $n(h)$ is the number of all possible data pairs separated by a distance $h$. The cross-variogram is a plot of semi-variance against the distance $h$. The easiest way to model the cross-variogram is to fit a linear model of co-regionalisation. All models (direct and cross) have the same shape and range, but may have different partial sills and nuggets. The cross-variogram Graph of the three earthworms species were both drawn thanks to the package 


\section{Macrothink}

'Gstat' from Matheron (1971).

\section{Results}

\subsection{Density of Earthworm Species}

Table 1 summarizes earthworm density data in the three stands of vegetation. Millsonia omodeoi, Chuniodrilus zielae, Chuniodrilus palustris, Chuniodrilus spl and Stuhlmannia porifera were the most abundant in grassy savanna. The student $t$ test indicated that the highest density of earthworm was obtained in grassy savanna have followed by forest and woody savanna $(\mathrm{p}<0.01)$.

Table1. Density of earthworms $\left(\mathrm{ind} / \mathrm{m}^{2}\right)$ in the three stands of vegetation in rainy season (mean \pm SE, $n=100$ )

\begin{tabular}{|l|c|c|c|}
\hline & Grassy savanna & Woody savanna & Forest \\
\hline Dichogaster saliens & $0.24 \pm 0.16$ & $1.6 \pm 0.59$ & $0.24 \pm 0.16$ \\
\hline Millsonia omodeoi & $21.68 \pm 1.4$ & $24.4 \pm 1.6$ & $7.72 \pm 0.94$ \\
\hline Sthulmania norifera & $23.84 \pm 2.47$ & $7.08 \pm 1.2$ & $1.08 \pm 0.65$ \\
\hline Chuniodrilus zielae & $21.96 \pm 2.74$ & $15.04 \pm 2.07$ & $13.36 \pm 1.57$ \\
\hline Chuniodrilus palustris & $11.68 \pm 1.79$ & $1.44 \pm 0.42$ & $12.68 \pm 1.95$ \\
\hline Agastrodrilus multivesiculatus & $1.64 \pm 0.29$ & $0.64 \pm 0.15$ & $6.44 \pm 1.14$ \\
\hline Dichogaster terrae nigrae & $0.72 \pm 0.22$ & $1.56 \pm 0.3$ & $0.96 \pm 0.24$ \\
\hline Dichogaster baeri & $0.92 \pm 0.25$ & $3.28 \pm 0.78$ & $3.4 \pm 1$ \\
\hline Dichogaster agilis & $3.56 \pm 0.65$ & $11.44 \pm 1.32$ & $27.88 \pm 2.19$ \\
\hline Agastrodrilus opistoginus & $0.88 \pm 0.4$ & $0.76 \pm 0.46$ & $0.72 \pm 0.34$ \\
\hline Millsonia sp1 & $0.2 \pm 0.08$ & $0.32 \pm 0.21$ & $0.52 \pm 0.15$ \\
\hline Chuniodrilus sp1 & $9.16 \pm 2.15$ & $4.44 \pm 1.26$ & $8.96 \pm 1.56$ \\
\hline Millsonia lamtoiana & 0 & $0.88 \pm 0.2$ & $1.28 \pm 0.27$ \\
\hline Hyperiodrilus africanus & 0 & $0.08 \pm 0.56$ & 0 \\
\hline Dichogaster eburnea & 0 & $1.04 \pm 0.65$ & $2.24 \pm 2.1$ \\
\hline Dichogaster sp2 & 0 & $0.84 \pm 0.37$ & 0 \\
\hline Chunidrilus sp2 & 0 & $4.44 \pm 1.26$ & $2.76 \pm 0.94$ \\
\hline Dichogaster sp3 & 0 & $0.52 \pm 0.41$ & $0.64 \pm 0.52$ \\
\hline Total & $96.48 \pm 12.6$ & $75.36 \pm 12.55$ & $90.88 \pm 15.72$ \\
\hline Number of species & 12 & 18 & 16 \\
\hline
\end{tabular}

\subsection{Correlation Matrix}

Table 2 shows that Millsonia omodeoi exhibits significantly negative association with the Eudlilidae species. Especially there is significant negative association between Millsonia omodeoi and Stuhlmannia porifera, Millsonia omodeoi and Chuniodrilus zielae and Millsonia omodeoi and Chuniodrilus sp1. In spite of a negative relationship between Millsonia omodeoi and the last species of Eudrilidae (Chuniodrilus palustris), this correlation is not significant. 


\section{Macrothink}

Table2: Correlation matrix between earthworm species in grassy savanna.

\begin{tabular}{|c|c|c|c|c|c|c|c|c|c|c|c|c|}
\hline & Dich_sal & Mil_omo & Sth_por & Chu_zie & Chu_pal & Aga_mul & Dich_ter_nigr & Dich_bae & Dich_agi & Aga_opi & Mil_sp1 & Chu_sp1 \\
\hline Dich_sal & - & & & & & & & & & & & \\
\hline Mil_omo & 0.01 & - & & & & & & & & & & \\
\hline Sth_por & 0.02 & $-0.31 * *$ & - & & & & & & & & & \\
\hline Chu_zie & -0.06 & $-0.24 *$ & $0.39^{* * *}$ & - & & & & & & & & \\
\hline Chu_pal & -0.07 & -0.10 & $0.32 * *$ & -0.01 & - & & & & & & & \\
\hline Aga_mul & -0.08 & 0.01 & 0.09 & 0.06 & 0.03 & - & & & & & & \\
\hline Dich_ter_nigr & -0.05 & 0.04 & -0.08 & 0.03 & -0.12 & $0.27 * *$ & - & & & & & \\
\hline Dich_bae & 0.03 & 0.10 & -0.10 & -0.06 & 0.01 & 0.12 & 0.11 & - & & & & \\
\hline Dich_agi & -0.08 & 0.08 & -0.19 & -0.16 & -0.02 & -0.06 & -0.10 & -0.11 & - & & & \\
\hline Aga_opi & -0.03 & -0.07 & 0.11 & 0.11 & 0.06 & -0.05 & -0.03 & 0.02 & -0.04 & - & & \\
\hline Mil_sp1 & -0.03 & -0.03 & -0.11 & -0.17 & 0.15 & -0.13 & 0.03 & 0.07 & -0.04 & -0.05 & - & \\
\hline Chu_sp1 & 0.01 & $-0.30 * *$ & 0.17 & -0.07 & 0.09 & -0.16 & -0.09 & 0.03 & -0.13 & -0.05 & -0.01 & - \\
\hline
\end{tabular}

Dich_sal = Dichogaster saliens; Mil_omo = Millsonia omodeoi; Sth_por = Sthulmania porifera; Chu_zie $=$ Chuniodrilus zielae; Chu_pal $=$ Chuniodrilus palustris; Aga_mul = Agastrodrilus multivesiculatus; Dich_ter_nigr = Dichogaster terrae nigrae; Dich_bae = Dichogaster baeri; Dich_agi = Dichogaster agilis; Aga_opi = Agastrodrilus opistoginus; Mil_sp1 = Millsonia sp1; Chu_sp1 = Chuniodrilus sp1; bold $* *=$ Correlation is negatively highly significant at $1 \%$ probability level; ; bold $*=$ Correlation is negatively significant at $5 \%$ probability level; others $*=$ correlation is positively significant at $0.1 \%(* * *)$ or at $1 \%(* *)$

\subsection{Spatial Co-Distribution of Negative Association}

The spatial distribution is well structured for the species in negative interaction (Figure 1). The larger densities of Millsonia omodeoi are found at locations which contrast with the larger densities of Eudrilidae species. If we compare the Eudrilidae species distribution, it becomes evident that these species are in positive association. The larger densities of Eudrilidae species have fairly a similar spatial distribution. This figure confirms the correlations found above. 


\section{Macrothink}
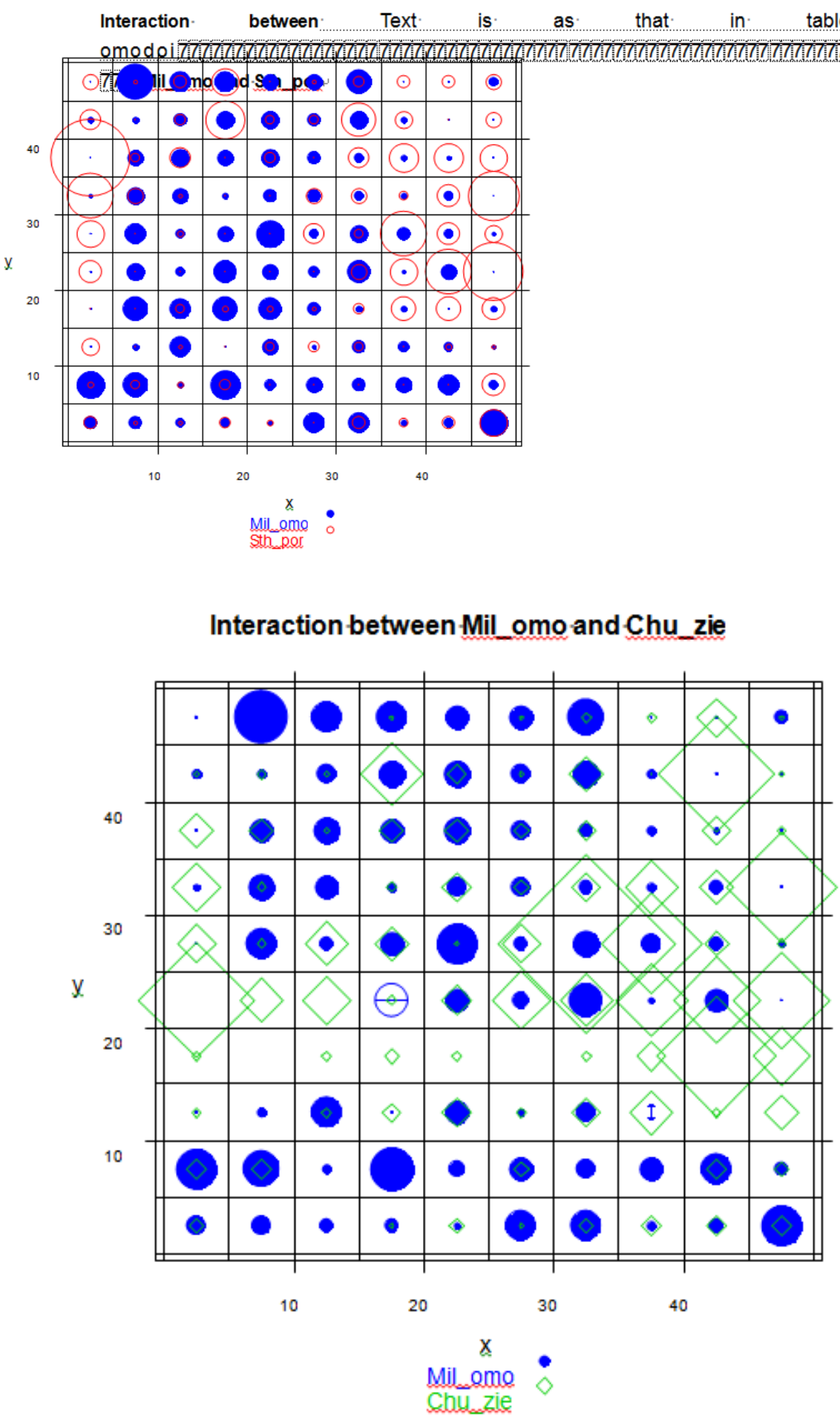

Figure 1. Spatial distribution between Milsonia omodeoi and Eudrilidae species

Text is as that in table 2

\subsection{Variogram}

From the three models of variogram tested, spherical model seemed to fit well the experimental data of Millsonia omodeoi, Stuhlmannia porifera and Chuniodrilus zielae. We have failed to fit 


\section{Ml Macrothink}

Chuniodrilus spl with one of the three models. Neither the omnidirectionnal variogram (isotropy) nor the directional variogram (anisotropy) fitted with satisfactory the experimental data of Chuniodrilus sp1. Table 3 summarizes the variograms parameters. The relative variance $[\mathrm{C} /(\mathrm{C}+\mathrm{C} 0)]$ was high, it varied around $70 \%$ for the three earthworms species. The variogram revealed the presence of a spatial autocorrelation up to $22.31 \mathrm{~m}$ for C. zielae, $36.96 \mathrm{~m}$ for $M$. omodeoi and $50.46 \mathrm{~m}$ for $S$. porifera.

Table 3. Variogram model parameters

\begin{tabular}{|l|l|l|l|l|l|l|}
\hline & Model & $\begin{array}{l}\text { Nugget } \\
(\mathrm{C} 0)\end{array}$ & $\begin{array}{l}\text { Partial } \\
\text { sill (C) }\end{array}$ & $\begin{array}{l}\text { Range (a) } \\
\text { (metre) }\end{array}$ & $\begin{array}{l}\text { Relative structural } \\
\text { variance (\%) }\end{array}$ & $\begin{array}{l}\text { Remaining structural } \\
\text { variance (\%) }\end{array}$ \\
\hline $\begin{array}{l}\text { Millsonia } \\
\text { omodeoi }\end{array}$ & Spherical & 4.65 & 9.66 & 36.96 & 67.50 & 32.50 \\
\hline $\begin{array}{l}\text { Stuhlmannia } \\
\text { porifera }\end{array}$ & Spherical & 9.92 & 26.68 & 50.46 & 72.90 & 27.10 \\
\hline $\begin{array}{l}\text { Chuniodrilus } \\
\text { zielae }\end{array}$ & Spherical & 8.36 & 18.40 & 22.31 & $68 ; 76$ & 31.24 \\
\hline
\end{tabular}

\subsection{Cross-Variogram}

Up till now we have worked with variograms, and variogram models as separate objects (direct variograms). This is sufficient for univariate geostatistics. For multivariate analysis, we use the fit.lmc method ("fit linear model of co-regionalization"). This takes the initial estimate, fits all the variograms, and then each of the partial sills is adjusted (by least squares) to the closest value that will result in a positive definite matrices. Table 4 summarizes the direct variogram and cross variogram parameters adjusted by least squares. When we compare the three direct variograms with the parameters that we have determined for each one separately, to see how much fitting the linear model of co-regionalisation adjusted the fit to each variable separately, we can see that the total sills are hardly affected (in all cases raised slightly except for M.omodeoi). The partial sills are adjusted even less in the case of direct variogram. Thus the common starting point for the linear model of co regionalisation is satisfactory. The spatial dependence between the different species explains the main relative variance $[\mathrm{C} /(\mathrm{C}+\mathrm{C} 0)]$ up to $93 \%$ for negative association between M.omodeoi - S.porifera and 97\% for positive association between S.porifera - C.ziele. The ranges are still constant, because they are not adjusted by the fit.lmc method. The range 36.96 is the range of M.omodeoi, the common starting point for the linear model of co regionalisation.

Figure 2 shows the fit models of co regionalisation. We can observe the negative interaction between M.omodeoi and S.porifera on one hand and on other hand between M.omodeoi and C.ziele.

Table 4. Co Regionalisation Parameters

\begin{tabular}{|l|l|l|l|l|l|l|}
\hline & Model & $\begin{array}{l}\text { Nugget } \\
(\mathrm{C} 0)\end{array}$ & $\begin{array}{l}\text { Partial sill } \\
(\mathrm{C})\end{array}$ & $\begin{array}{l}\text { Range (a) } \\
(\text { metre })\end{array}$ & $\begin{array}{l}\text { Relative structural } \\
\text { variance }(\%)\end{array}$ & $\begin{array}{l}\text { Remaining } \\
\text { variance }(\%)\end{array}$ \\
\hline \multicolumn{7}{|c|}{ Direct variogram } \\
\hline Millsonia omodeoi & Spherical & 9.03 & 3.20 & 36.96 & 26.16 & 73.83 \\
\hline
\end{tabular}




\begin{tabular}{|c|c|c|c|c|c|c|}
\hline $\begin{array}{l}\text { Stuhlmannia } \\
\text { porifera }\end{array}$ & Spherical & 16.81 & 28.08 & 36.96 & 62.55 & 37.45 \\
\hline Chuniodrilus zielae & Spherical & 25.41 & 33.53 & 36.96 & 56.90 & 43.1 \\
\hline \multicolumn{7}{|c|}{ Cross variogram } \\
\hline $\begin{array}{l}\text { M.omodeoi } \\
\text { S.porifera }\end{array}$ & Spherical & 0.68 & -8.90 & 36.96 & 92.90 & 7.1 \\
\hline M.omodeoi-C.ziele & Spherical & -0.81 & -4.46 & 36.96 & 84.63 & 15.37 \\
\hline S.porifera-C.ziele & Spherical & 0.79 & 21.98 & 36.96 & 96.53 & 3.47 \\
\hline
\end{tabular}

\section{Discussion}

Description of spatial patterns is rarely a goal per se. Rather; one generally wants to know the mechanism by which these spatial patterns are created. In this paper we use geostatistical analysis to assess the spatial dependence between different species.

Our results revealed among earthworm community two groups of species appeared of interest in term of association. The Eudrilidae species (Stuhlmannia porifera, Chuniodrilus zielae, and Chuniodrilus spl) on the one part were negatively associated with $M$. omodeoi (Megascolecidae) on the other part. This study showed that $M$. omodeoi might be in competitive interaction with Eudrilidae species. This competitive interaction was detected through reduced density of one competitor when they spatially collocated. Spatial distribution showed that $M$. omodeoi has an advantage in central grid while Eudrilidae species dominate on the edges.

Several authors (Baker and al., 2002; Lowe and Butt, 1999) have suggested that interspecific competition in earthworms is most likely to be important between pairs of species which have broad niche overlap, such as within pairs of anecic or endogeic species. Indeed S. porifera, $C$. zielae, C. spl and M. omodeoi belong in the same ecological category of the soil - dwelling (earthworms which live within the soil and feed on humic substances or dead roots), let us suppose that the competition is due for the same resource which is limited in grassy savanna. Abbadie and et al., (2006) concluded that in Lamto, like in most savanna ecosystems, the accumulation of organic matter in soil is low compared to the high primary productivity. The burning of aboveground biomass strongly decreases the input of plant debris to soil.

The present study confirms the result of Blanchart et al., (1997). They found the opposite structure between $C$. zielae and S. porifera in one part and $M$. omodeoi in other part. Large worms $M$. omodeoi are mainly responsible for the formation of the macroaggregate structure by creating aggregates $>0.5 \mathrm{~mm}$ and large macropores. In the absence of any factor regulating their effects, and especially when earthworm biomass is high, the soil is progressively compacted ("compacting" effect). Water infiltration is thus disrupted and environmental conditions are no longer suitable for earthworms. Small Eudrilid earthworms destroy large aggregates, which are mostly ageing cast, and excrete small aggregates ("decompacting" effect). In that respect the physical structure of earthworms casts deeply influences the further dynamics of soil organic matter.

The significant positive association between $C$. zielae and $S$. porifera might be due to the fact 
that these two species belong to the same functional group and their activities are complementary (“decompacting” effect).

Our findings are in contradiction to the result of Rossi (2003a). This author used the SADIE (Spatial Analysis using Distance IndicE) to assess the spatial distribution and spatial dependence of two earthworm groups (Sthulmania porifera and Chuniodrilus zielae (Eudrilidae) on the one part and Millsonia anomala (old name of M. omodeoi) (Megascolecidae) on the other part in grass savanna of Lamto. No spatial association was reported between the clusters of these earthworm groups. This lends weight to the view that geostatistical methods are accurate to assess spatial dependence over various spatial scales. Spatial methods based on indices carry limited information since these methods do not take into account the actual location of sampling points with respect to each other.

The absence of association is observed somewhere else. This absence might be due to real absence of association between species or might be due to an absence of linear relationships between these species. On the contrary our model of coregionalisation assumes linear model of cross-variogram.

Association, in either the positive or negative direction cannot unambiguously infer the action of specific processes from the examination of patterns alone. Among other factors environmental requirements can also lead to a positive or negative association. Positive associations between two species can occur when both select the same habitat or have the same environmental requirements. Conversely, negative associations can occur if the species have differing ecological requirements. Moreover, the stochastic processes can generate associations of patterns of species.

\section{Conclusion}

In conclusion, the present work identifies among earthworm community two groups of species of interest in term of association. This study indicates that the competitive interaction structures the community and this competition is detected through reduced density of one competitor when they spatially collocated. It seems like this competition occurred for limited soil organic matter in grassy savanna.

\section{References}

Abbadie L., Nacro H. B, \& Gignoux J. (2006). Soil Carbon and Organic Matter Dynamics in Lamto Structure, Functioning, and Dynamics of a Savanna Ecosystem. Springer-Verlag, New-York, Ecological Studies, 179, 412.

Amarasekare P. (2003). Competitive coexistence in spatially structured environments: a synthesis. Ecology Letters, 6, 1109-1122. http://dx.doi.org/10.1046/j.1461-0248.2003.00530.x

Baker G., Carter P., Barett V., Hirth J, Mele P., Gourley C. (2002). Does the deep-burrowing earthworm, Aporrectodea longa, compete with resident earthworm communities when introduced to pastures in south-eastern Australia? European Journal of Soil Biology 38, 39-42. http://dx.doi.org/10.1016/S1164-5563(01)01121-9 
Blanchart E., Lavelle P., Braudeau E., Le Bissonnais Y. C. (1997). Valentin, Regulation of soil structure by geophagous earthworm activities in humid savannas of Côte d'Ivoire. Soil Biology \& Biochemestry 29, 431-439. http://dx.doi.org/10.1016/S0038-0717(96)00042-9

Bohlen P. J, \& Edwards C. A. (1995). Earthworm effects on $\mathrm{N}$ dynamics and soil respiration in microcosms receiving organic and inorganic nutrients. Soil Biology \& Biochemestry, 27(3), 341-348. http://dx.doi.org/10.1016/0038-0717(94)00184-3

Brown G. G., Barois I., Lavelle P. (2000). Regulation of soil organic matter dynamics and microbial activity in the drilosphere and the role of interactions with other edaphic functional domains. European Journal of Soil Biology, 36,177-98. http://dx.doi.org/10.1016/S1164-5563(00)01062-1

Cressie N. A. C. (1993). Statistics for spatial data revised edition. New York. John Wiley \& Sons, Inc. 900p.

Csuzdi C., Tondoh J. E. (2007). New and little-known earthworm species from the Ivory Coast (Oligochaeta: Acanthodrilidae: Benhamiinae and Eudrilidae). Journal of Natural History 41.

De Ruiter P. C., Moore; J. C, Zwart K. B., Bouwman L. A., Hassink J., Bloem J., de Vos J. A., J. C. Y., Marinissen, Didden W. A. M., Lebbink G, \& L. Brussaard. (1993). Simulation of nitrogen mineralization in belowground food webs of two winter wheat management practices. Journal of Applied Ecology, 30, 95-106. http://dx.doi.org/10.2307/2404274

Hättenschwiler S., Tiunov A. V, \& Scheu S. (2005). Biodiversity and litter decomposition in terrestrial ecosystems. Annual Review Ecology. Evolution Systematic. 36, 191-218. http://dx.doi.org/10.1146/annurev.ecolsys.36.112904.151932

Rossi, J. P. (2003b). Short-range structures in earthworm spatial distribution. Pedobiologia, 47, 582-587.

Jiménez J. J., Rossi J. P., \& Lavelle P. (2001). Spatial distribution of earthworms in acid-soil savannas of the eastern plains of Colombia. Applied Soil Ecology, 17, 267-278. http://dx.doi.org/10.1016/S0929-1393(01)00133-0

Lavelle P. (1978). Les vers de terre de la savane de Lamto (Côte d'Ivoire): peuplements, populations et fonctions dans l'écosystème. Thèse d'Etat. Université Paris VI. Publication. Laboratoire de Zoology. ENS n ${ }^{\circ} 12$.

Lowe C. N., Butt K. R. (1999). Interspecific interactions between earthworms: A laboratory based investigation, Pedobiologia, 43, 808-817.

Matheron G. (1971). The theory of regionalized variables and its applications. Cahier du Centre de Morphologie de Mathematique de Fontainebleau N5.

Nuutinen V., Pitkänen J., Kuusela E., Wildbom T., \& Lohilahti H. (1998). Spatial variation of earthworm community in relation to soil properties and yield on a grassclover field. Applied Soil Ecology, 8, 85-94. http://dx.doi.org/10.1016/S0929-1393(97)00063-2

R Development Core Team R. (2010): A language and environment for statistical computing. R 


\section{Macrothink}

Journal of Biology and Life Science ISSN 2157-6076 2015, Vol. 6, No. 1

Foundation for Statistical Computing,Vienna, Austria. ISBN 3-900051-07-0, URL http://www.R-project.org/.

Rossi J. P., Lavelle P., \& Albrecht A. (1997). Relationships between spatial pattern of the endogeic earthworm Polypheretima elongata and soil heterogeneity. Soil Biology and Biochemistry, 29, 485-488. http://dx.doi.org/10.1016/S0038-0717(96)00105-8

Rossi J. P. (2003a). Clusters in earthworm spatial distribution. Pedobiologia, 47, 490-496.

Rossi R. E., Mulla D. J., Journel, A. G., Franz E. H. (1992). Geostatistical tools for modeling and interpreting ecological spatial dependence. Ecology Monograph, 62, 277-314. http://dx.doi.org/10.2307/2937096

Schaefer, M. (1991). Ecosystem processes: Secondary production and decomposition. In Temperate Deciduous Forests. Ecosystems of the World, ed. E R ohrig, B Ulrich, 7, 175-218. Amsterdam: Elsevier.

Scheu S, Schlitt N., Tiunov A. V., Newington J. E., Jones T. H.( 2002). Effects of the presence and community composition of earthworms on microbial community functioning. Oecologia 133, 254-60. http://dx.doi.org/10.1007/s00442-002-1023-4

Shaw C., Pawluk S. (1986). Faecel microbiology of Octolasion tyrtaeum, Aporrectodea turgida \& Lumbricus terrestris and its relation to the carbon budgets of three artificial soils. Pedobiologia, 29, 377-89.

Verhoef, H. A, \& Brussaard, L. (1990). Decomposition and nitrogen mineralization in natural and agro-ecosystems: The contribution of soil animals. Biogeochemistry 11, 175-211. http://dx.doi.org/10.1007/BF00004496

Whalen J. K. (2004). Spatial and temporal distribution of earthworm patches in corn field, hayfield and forest systems of southwestern Quebec, Canada. Applied Soil Ecology 27, 143-151. http://dx.doi.org/10.1016/j.apsoil.2004.04.004

\section{Copyright Disclaimer}

Copyright for this article is retained by the author(s), with first publication rights granted to the journal.

This is an open-access article distributed under the terms and conditions of the Creative Commons Attribution license (http://creativecommons.org/licenses/by/3.0/). 